\title{
Growth, yield and grain nutrients response of wheat (Triticum aestivum L.) to biochar,lime and farmyard manure amendment of the croplands in southern Ethiopia.
}

Mekdes Lulu ( $\square$ lulumekdes68@gmail.com )

Hawassa University https://orcid.org/0000-0002-4986-7022

Bekele Lemma

Hawassa University

Legesse Hidoto

Southern Agricultural research Institute

\section{Research}

Keywords: Biochar, Cropland, Grain nutrient concentration,Growth parameters, Yield component

Posted Date: February 26th, 2020

DOI: https://doi.org/10.21203/rs.2.24567/v1

License: () (7) This work is licensed under a Creative Commons Attribution 4.0 International License.

Read Full License 


\section{Abstract}

Background: Soil fertility decline in agricultural land is due to intensive cropping system, shortening of the fallow period, reduced manure application, extensive use of crop residues as fuel or fodder and removal of ground cover. This study investigated the effect of biochar (BC), lime and farmyard manure (FYM) on growth, yield and grain nutrient of wheat on croplands at two sites in the southern Ethiopia.

Result: Site significantly $(\mathrm{P}<0.05)$ influenced most growth parameters, yield and yield components, and grain nutrient concentration of wheat. The effects of BC, lime, and FYM were significant ( $p \leq 0.001)$ on straw yield, grain yield, and total biomass. However, BC (5t ha -1$)$ produced the highest straw yield, grain yield and total biomass. The effects of $B C, F Y M$ and lime were significant $(P<0.001)$ on spike length and seed per spike. Similarly, BC and lime significantly $(P<0.001)$ affected plant height, number of total and productive tillers. $\mathrm{BC}(5 \mathrm{t}$ ha -1$)$ gave the highest plant height, total tillers and productive tillers, maximum number of seeds per spike,while FYM (10 t ha -1) produced the highest spike length. Biochar, FYM and lime significantly ( $p \leq 0.001$ ) affected thousand seed weight, but only $B C$ had significant $(p \leq 0.001)$ effect on harvest index. Biochar ( $5 \mathrm{t}$ ha -1 )and FYM (10 t ha -1 )produced the highest heaver thousand seed weight and the highest harvest index. Biochar significantly $(P<0.05)$ increased the concentrations of $P$ and $\mathrm{K}$ of wheat grain. On the other hand, the highest effect on grain $\mathrm{Ca}$ concentration was from the application of lime while the highest effect on grain $\mathrm{N}$ concentration was from the application FYM (10 $t$ ha -1 ).

Conclusion: The superior effect from $\mathrm{BC}$ was attributed to improvements in soil $\mathrm{pH}, \mathrm{CEC}$, nutrient availability and water retention. In general, the use of $\mathrm{BC}$ could be better option to soil amendment for wheat production on croplands of smallholder farmers.

\section{Background}

Wheat (Triticum aestivum, L.) is one of the most important cereal crops in terms of area and production. Ethiopia is the largest wheat producers in sub-Saharan Africa (Minot et al. 2015) with an estimated area of 1.70 million ha and production of 4.6 million ton (CSA, 2018). In Ethiopia, the productivity of wheat has increased from 1.3 tha $^{-1}$ in 1994(CSA 1995) to $2.7 \mathrm{t} \mathrm{ha}^{-1}$ in 2018(CSA 2018). Wheat production has grown significantly over the past decades following government programs and initiatives implemented to drive agricultural growth and food security. However, the current wheat production is inadequate to fill the gap over the past decades (Minot et al., 2015) due to low soil fertility and soil fertility management practices (Gebresselassie 2002).In 2013/14 the country imported 1.39 million metric ton, which is about 34 percent of the domestic production and above 160 percent of the marketed wheat in the country (Minot et al. 2015).

Soil fertility decline in agricultural land is due to intensive cropping system, shortening of the fallow period, reduced manure application, extensive use of crop residues as fuel or fodder and removal of ground cover (Amede et al. 2001).The nutrient balance for the Sub-Sharan Africa (SSA) appears to be negative because nutrient loses is greater than nutrient inputs (Agegnehu et al. 2014). Moreover, studies indicated that most 
Ethiopian agricultural soils have low fertility due to low rate of return of biomass to crop fields, continuous nutrient uptake of crops, low fertilizer use and insufficient organic matter application (Gebrekidan 2003). The major constraints to agricultural production in Ethiopian highlands could be the decline in soil organic matter, nutrient imbalance as well as soil acidity problem (Agegnehu et al. 2014).The combined application of organic and inorganic fertilizer is a productive approach to improve soil fertility (Efthimiadou et al. 2010).

Studies in SSA including Ethiopia have reported the effect of inorganic and organic fertilizers on crop yield (Efthimiadou et al. 2010; Waseem et al. 2013). The benefits of inorganic fertilizer have been widely demonstrated since the green revolution (Vanlauwe et al. 2010); however, most smallholder farmers in SSA cannot afford the recommended fertilizer due to high cost. Moreover, the application of inorganic fertilizer alone is not a sustainable solution for improving soil fertility (Agegnehu et al. 2014). Other studies have reported the effect of application of liming materials on crop yield (Negash and Rezene 2015).Little studies reported the use of farmyard manure (FYM)on grain yield of wheat products (Efthimiadou et al. 2010). Amlinger et al. (2007) studied the effect of organic fertilizers by adding Ca in the form of calcium carbonate. Enujeke (2013) found that application of poultry manure to improve maize productivity in Asaba area of Delta State. Similarly, Ranva and Singh (2006) investigated the effect of Vermi compost on wheat growth parameters and yield attributes. Biochar $(\mathrm{BC})$ is an organic fertilizer, a form of charcoal, produced at a relatively high temperature $\left(400-700^{\circ} \mathrm{C}\right)$ in oxygen limited combustion (pyrolysis) of plant biomass (Lehmann and Joseph 2009).Studies have reported the effect of BC amendment on yield components of different crops in different parts of the world (Agboola and Moses 2015; Haileselassie et al. 2015;Faruqueet al. 2017). A study by Faruque et al. (2017) investigated the utilization of BC on the productivity mulberry plant. The effect of BC was studied on growth and yield attributes of in the Mediterranean climate conditions (Manue/ et al. 2014).A review on biochar studies indicated that the majority of the studies have been carried out in developed countries than developing countries (Agegnehu et al. 2016). Few published reports are available on the investigation of the influence of $B C$ on crop yield in SSA as well as Ethiopia (Abewa et al. 2013; Hailesilasie et al. 2015). Therefore, this study was aimed to investigate the effect of $\mathrm{BC}$, lime, and FYM on growth parameters, yield and nutrient concentration in grain and straw of wheat(Triticum aestivum, L.) in croplands at two sites in Wolaita Zone, Southern Ethiopia.

\section{Materials And Methods}

\subsection{Experimental site}

A field experiment was conducted on farmer fields at Gununo Hamusand Waja Kero kebeles of Damot Sore and Sodo Zuria districts of Wolaita Zone in southern Ethiopia, respectively (Figure 1). Soddo, the capital of Wolaita zone, is located $329 \mathrm{~km}$ south of Addis Ababa. The geographical coordinates of Gununo Hamusis $37^{\circ} 39^{\prime} 0^{\prime \prime}-37^{\circ} 43^{\prime} 0^{\prime \prime} \mathrm{E}, 6^{\circ} 55^{\prime} 0^{\prime \prime}-7^{\circ} 5^{\prime} 0^{\prime \prime} \mathrm{N}$ and Waja Kero at $37^{\circ} 40^{\prime} 0^{\prime \prime}-37^{\circ} 45^{\prime} 0^{\prime \prime} \mathrm{E}, 6^{\circ} 50^{\prime} 0^{\prime \prime}-6^{\circ} 55^{\prime} \mathrm{O}^{\prime \prime} \mathrm{N}$. Gununo Hamus is located $44 \mathrm{~km}$ southwest of Soddo town, while the Waja Kero is $5 \mathrm{~km}$ west of Soddo. The altitude at Gununo Hamus and Waja Kero ranges from 1900 to $2100 \mathrm{~m}$ above sea level (asl). The topography of the study areas is level to sloping land with slopes less than $16 \%$. The rain fall in the area 
was characterized by bimodal distribution pattern and the main rainy season (Meher) is between June and end of September and Belg is from late February to late March or early April. The mean monthly average temperatures $\left({ }^{\circ} \mathrm{C}\right)$ and mean monthly total rainfall $(\mathrm{mm})$ of one year within the two sites are shown in Figure 2. According to FAO/UNESCO soil map of the world, the dominant soil at GununoHamus is Ochric Andosol and that of Waja Kero is EutricNitisols(http://www.fao.org/geonetwork/srv/en/metadata.show\%3 Fid=14116).

\subsection{Experimental materials, treatments and Design}

The wheat variety 'Kakaba' was used as a test crop which was obtained from Wolaita zone agricultural office. Lime, BC and FYM were used as soil amendments. The experimental design was randomized complete block in factorial arrangement with three replications. The 27 treatments applied included BC, FYM and lime and each treatment applied at three rates. Farmyard manure (cow dung and decomposed for two months before application) was collected from farmer households in the study areas. It was applied at rates 0,5 , and 10 tha $^{-1}$ manually 2 weeks before sowing and incorporated using a spade within $24 \mathrm{~h}$. Biochar used in the study was a crashed finer residue of charcoal collected from commercial charcoal sellers in Wolaita Soddo town. Our assessment indicated that the charcoal producers use acacia tree species Acacia penninrvisis which locally termed Odorua. The biochar in a charcoal form was ground and sieved ( $0.25 \mathrm{~mm}$ mesh size) before application. It was applied at rates 0,2 , and 5 tha $^{-1}$ manually 2 weeks before sowing and incorporated within $24 \mathrm{~h}$ of using a spade. The $\mathrm{CaCO}_{3}$ with a purity of $98 \%$ was used as the source of lime. The limestone $\left(\mathrm{CaCO}_{3}\right)$ was obtained from Wolaita Zone Office of Agriculture. Lime was applied at three rates in both sites, based on the lime requirement determination (LR). It was applied broadcasting manually at the surface soil $(0-15 \mathrm{~cm})$ month before sowing. The lime requirement determined by the Shoemaker, Mclean and Pratt (SMP) buffer method to raise the $\mathrm{pH}$ to target $\mathrm{pH}$ values of 6.5 is presented for two sites (Shoemaker et al., 1961). Accordingly, pH 5.6 and 5.4 were taken for determining the lime rate used at Gununo Hamus and Waja Kero sites, respectively. From the determination of lime requirement of soils of Gununo Hamus, lime was applied at the rates of 0, 2.9, 5.7 tha ${ }^{-1}$ while for Waja Kero $0,3.75,7.5$ tha $^{-1}$ to soil samples.

The fertilizers were obtained from Southern Nations Nationalities and Peoples Regional Bureau of Agriculture and Natural Resources, soil testing laboratory. The mineral fertilizer plots received $120 \mathrm{~kg} \mathrm{~N} \mathrm{ha}^{-}$

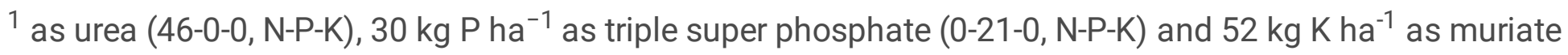
of potash (0-0-60, N-P-K). Half the $\mathrm{N}$ and full $\mathrm{P}$ and $\mathrm{K}$ were applied just before sowing of wheat. The remaining $\mathrm{N}$ was applied as a top dressing at the tillering stage (35 days after sowing). All the treatments were assigned randomly to the plots within a block. The spacing between plots and blocks were $0.5 \mathrm{~m}$ and $1.5 \mathrm{~m}$, respectively. Wheat was sown at the seeding rate of $100 \mathrm{~kg} \mathrm{ha}^{-1}$ ina plot size of $3 \mathrm{~m}$ by $2 \mathrm{~m}$ having row spacing of $20 \mathrm{~cm}$.

\subsubsection{Agronomic data collection and measurement}


Ten plants were randomly selected from each plot and plant height was measured from the base to the spike tip excluding awns using measuring tape and averaged to each plot (Bhatta et al. 2012).From these data the number of total and productive tillers per plant were selected effective and non-effective tillers plant were counted from each plot randomly and averaged to each plots. To measure spike length, excluding the awns, was measured using measuring tape and averaged to each plot. Number of grains per spike, was selected and filled and unfilled grains spike ${ }^{-1}$ were counted and averaged to each plot. Total biomass was determined after sun drying from the total weight of harvest at each plot. Grain yield was measured from each plot after air drying and then weighed carefully and the straw yield was obtained by the difference between total biomass and grain yield. Like grain yield, straw yield and total biomass were expressed as $\mathrm{kg} \mathrm{ha}^{-1}$.Yield components were calculated using standard protocols (Pask et al. 2012). From these data the number hundred seeds weight were counted from sample of each plot after sun drying and measured by an electrical balance and converted into thousand grain weights in $\mathrm{kg}$. Harvest index(\%) was calculated as the fraction of grain yield to the total biomass times 100 was described by Huhm(1990a). Weeds were managed by hand-weeding once followed by two hoeing by using a manually operated wheelhoe. Crop was harvested by hand and separated into grains (yield) and the rest of biomass.

\subsubsection{Plant tissue analysis}

Plant was sampled for grain from each plot was collected after harvesting time. The plant samples were dried in air then ground in stainless steel Wiley mill and sieved $(0.5 \mathrm{mmmesh}$ size). Ca and $\mathrm{K}$ in the plant sample were determined after acid digestion method with $\mathrm{H}_{2} \mathrm{O}_{2} / \mathrm{H}_{2} \mathrm{SO}_{4}$ (Okaleboet al. 2002). Then $\mathrm{Ca}$ was analyzed by atomic absorption spectrophotometer, while $\mathrm{K}$ was analyzed by flame photometer. $\mathrm{P}$ measured as described by Murphy and Riley (1962). The percent nitrogen content was determined by Kjedahl method as described by Jackson (1958).

\subsection{Statistical analysis}

All ofthe data were analyzed using analysis of variance (ANOVA) with statistical analysis system (SAS) program(SAS, 2017). The least significant difference (LSD) test was used to separate significantly difference treatment mean were used at $\mathrm{P} \leq 0.05$ level.

\section{Result}

\subsection{Effect of biochar, lime and farmyard manure on growth parameters}

The effect of site was significant $(P<0.05)$ for all growth parameters. The effects of $B C$, lime as well as interaction effects of site $\times B C$, site $\times F Y M$, site $\times B C \times F Y M$ and site $\times B C \times$ lime were highly significant $(P<$ 0.001 ) on plant height (Table 1). As presented in Table 2, plant height was higher at $5 \mathrm{t} \mathrm{ha}^{-1}$ of $\mathrm{BC}$ for both sites. The effects of $B C$, lime as well as interaction effects of site $x B C$, site $x B C \times$ lime were highly significant $(p \leq 0.001)$ on number of total and productive tillers (Table 1). The total tillers and productive tillers were higher at 5 tha $^{-1}$ of $B C$ for both sites (Table 2).Moreover, the effects of BC, FYM, lime and the interaction effects of site $\times \mathrm{BC}$, site $\times \mathrm{FYM}$ and site $\mathrm{x}$ lime were significant on spike length and seed per 
spike (Table 1). The longest spike length was at 10 tha $^{-1} \mathrm{FYM}$ in both sites (Table 2). Likewise, the maximum number of seeds per spike was at $5 \mathrm{t} \mathrm{BC} \mathrm{ha}^{-1}$ in both sites (Table 2).

\subsection{Effect of biochar, lime and farmyard manure on yield and yield components}

The effect of site was significant $(P<0.001)$ for most yield and yield components. The effects of $B C, F Y M$, limeas well as interaction effects of site $x B C$, site $x$ lime and site $x B C x$ lime were highly significant $(p \leq 0.001)$ on grain yield, straw yield and total biomass (Table 3$)$. The highest grain yield, straw yield and total biomass were found for BC amendment $\left(5\right.$ tha $\left.^{-1}\right)$ in both sites (Table 4). The effects of BC, FYM, lime and interaction effect of site $\times B C$ and BC $\times$ FYM were highly significant $(p \leq 0.001)$ on thousand seed weight (Table 3). The heaver thousand seed weight was at $10 \mathrm{t} \mathrm{ha}^{-1}$ of FYM and $5 \mathrm{t} \mathrm{ha}^{-1}$ of BC in Gununo Hamus and Waja Kero, respectively (Table 4). The effects of BC, FYM and interaction effects of site $x B C$ and $B C \times$ FYM were highly significantly $(p \leq 0.001)$ on harvest index (Table 3$)$. The highest harvest index was found at $10 \mathrm{t} \mathrm{ha}^{-1}$ of FYM and $5 \mathrm{t} \mathrm{ha}^{-1}$ of BC in Gununo Hamus and Waja Kero, respectively (Table 4).

\subsection{Effects of biochar, lime and farmyard manure on grain nutrient content of bread wheat}

Site has significant effect $(P<0.001)$ on grain nutrient content of wheat (Table 5). The effects of $B C, F Y M$, lime were highly significant $(p \leq 0.001)$ on the concentration $N, P, K$ and $\mathrm{Ca}$ in grain of wheat (Table 3$)$. The highest grain $\mathrm{N}$ content was found at $10 \mathrm{tha}^{-1}$ of $\mathrm{FYM}$ and $5 \mathrm{t} \mathrm{ha}^{-1} \mathrm{BC}$ for both sites (Table 6). The highest grain $\mathrm{P}$ was found at $5 \mathrm{tha}^{-1} \mathrm{BC}$ for both sites (Table 6). The highest grain $\mathrm{K}$ was found at $5 \mathrm{t} \mathrm{ha}^{-1}$ of $\mathrm{BC}$ in Gununo Hamus and at $5 \mathrm{t} \mathrm{ha}^{-1}$ of $\mathrm{BC}$ for both sites (Table 6). The highest grain Ca was found at lime of 5.7 and $7.5 \mathrm{t} \mathrm{ha}^{-1}$ in Gununo Hamus and Waja Kero sites, respectively (Table 6). The interaction effects of BC and lime on wheat grain $\mathrm{N}, \mathrm{P}$ and $\mathrm{K}$ were highly significant $(\mathrm{p} \leq 0.001)$ (Table 5$)$. The highest grain $\mathrm{N}$ content (4.66\%) was found at $5 \mathrm{t} \mathrm{ha}^{-1}$ of BC with $2 \mathrm{t} \mathrm{ha}^{-1}$ lime (Fig 3). Similarly, the highest grain $\mathrm{P}(3.56 \%)$ was found from the application of at $5 \mathrm{t} \mathrm{ha}^{-1} \mathrm{BC}$ with 2 ton ha-1 Lime (fig 4). Moreover, the highest grain $\mathrm{K}$ content (2.84) was from the highest rated of BC and lime interaction (Fig. 5).

\section{Discussion}

The study showed that acacia biochar (BC) amendment could have higher effect on plant growth, yield and nutrient concentration of grain of wheat than farmyard manure and lime on cropland sin the southern Ethiopia. Consistent with the present study, BC showed high impact on plant growth parameters of annual crops such as maize, wheat, tomato and rice (Dunlop et al. 2015; Haileselassie et al. 2015; Agegnehu et al. 2016). Canadian agriBC improved growth of rice and sorghum (Asai et al. 2009). Agboola and Moses (2015) showed that application of rice husk BC to soil improved yield of soybean. Wheat grain yield increased by application of oil mallee waste BC (Solaiman et al. 2010).Similarly, mesquite BC increased grain and straw yields of wheat (Haileselassie et al. 2015). Maize BC amendment significantly increased the yield of maize and cassava (Abiven et al. 2015). Hossain et al. (2010) observed that sludge BC amendment increased the yield of cherry and tomato. Similarly, Dunlop et al. (2015) found that tomato crop green waste BC addition to soil improved the growth of tomato. Likewise, Edmunds (2012) reported 
that Switch grass BC application increased above-ground biomass yield in both switchgrass and sorghum. In contrast, other studies demonstrated that woodchip BC had no effect on growth and yield of rice and leaf beet (Lai et al. 2013).The finding of Borsari (2011) showed that maple BC had no effect on the growth parameters of pea and wheat. The significant variation of BC on plant growth and yield parameters among different studies in different sites could be ascribed to the effect of environmental factors (Shahzad et al. 2007).In review of $B C$, Lehmann et al.(2006) indicated BC in general improved the plant growth parameters and yield in the tropical environment. The effect of $\mathrm{BC}$ amendment on plant growth and yield parameters could be associated with improvements in soil pH, CEC, nutrient availability and water retention (Liang et al. 2014).The increase in plant growth and yield parameters was attributed to the improved soil nutrient supply and increased uptake of plant nutrients (Lehmann et al. 2006). Biochar addition to croplands was shown to enhance water retention, sorption capacity, nutrients availability, andsoil organic carbon (Laird 2008).Moreover, $B C$ characteristics also vary between experiments depending on feedstock and pyrolysis temperature (Bird 2015).

In the present study, the grain $\mathrm{N}$ content was highest for $\mathrm{FYM}$; grain $\mathrm{P}$ and $\mathrm{K}$ content was highest for BC; andCa content was highest for lime. Grain N, P, K and Ca concentrations were in the reported sufficiency range for all treatments, with $4-5 \%, 0.24-0.36 \%, 2-3 \%$ and $0.28-0.42 \%$,respectively(Barrett et al.,2017). The highest application of FYM (10 tha-1) rate significantly increased the $\mathrm{N}$ concentration in wheat grain. Likewise, Zahir and Ishaq (2006) reported that the maximum N concentration in grain wheat was found from higher FYM. The next highest $\mathrm{N}$ concentration was found from BC. The finding of Major et al. (2010) reported that $\mathrm{N}$ concentration in maize grains increased with application of ponderosa pine wood $B C$. $\mathrm{BC}$ increased P concentration in grain. Likewise, Gonzaga et al.(2017)found that biosolids (sludge) BC addition increased $\mathrm{P}$ concentration in grain of maize to provides improved seed formation and maturation thereby improved the above ground of maize. However, cassava stemBC had no significant effect on $\mathrm{P}$ content in green bean (Prapagdee and Tawinteung , 2017). The highest BC application ( $\left.5 \mathrm{t} \mathrm{ha}^{-1}\right)$ contributes to high $\mathrm{K}$ concentration in wheat grain due to improved exchangeable $\mathrm{K}$ in the soil. The finding by Prapagdee and Tawinteung (2017) showed increased K content in the grain bean by BC addition. Similar with Jeffrey et al. (2019) found that Lodgepole pine chip BC addition significantly increased the concentration of $\mathrm{K}$ in grain corn. With liming, increased $\mathrm{Ca}$ concentration in grain may indicate the increase in crop growth and yield due to the amelioration of Al toxicity. This in agreement with finding by Beukes et al. (2012) who reported that liming increased the Ca concentration in grain of maize crop. The high Cain grain wheat concentration with higher lime rate provides the soil have high soil exchangeable Ca attributed to improved Ca concentration in the soil (Bolanet al. 2003).

\section{Conclusion}

From the results of present study, it may be concluded that growth, yield and yield components as well as nutrient in wheat grain were significantly influenced by different levels of $\mathrm{BC}$, lime and farmyard manure on croplands. This study demonstrated that the application of higher $\mathrm{BC}$ rate was superior on its impact on growth parameters, yield, yield components and grain nutrients. The impact of $\mathrm{BC}$ was high on plant height, spike length, seed per spikelet, tillers, grain yield, straw yield and total biomass at $5 \mathrm{t} \mathrm{ha}^{-1}$. Further, 
the highest harvest index and the heaver thousand seed weight were produced in the higher farmyard manure rateat $10 \mathrm{t} \mathrm{ha}^{-1}$. Likewise, addition of higher $\mathrm{BC}$ rate at $5 \mathrm{t} \mathrm{ha}^{-1}$ produced thehigher nutrientsof $\mathrm{P}$ and $\mathrm{K}$ ingrain wheat. However, the higher $\mathrm{Ca}$ ingrain was obtained in higher lime rate at $5.7 \mathrm{t} \mathrm{ha-1}$ and 7.5 tha ${ }^{-1}$ owing to high Cacontent in lime. The higher $\mathrm{N}$ in grain was obtained in higher FYM rate at $10 \mathrm{t} \mathrm{ha}^{-1}$. The results showed that $\mathrm{BC}$ has enormous potential for the improvement of wheat growth and yield parameters as well as grain nutrients. Thus, BChas great potential for use as soil amendmenton croplands of the smallholder farmers in southern Ethiopia. We recommend further studies to be carried out to investigate the optimum amount BC needed for wheat production at different levels of mineral fertilizer.

\section{Abbreviations}

(BC) biochar, (FYM) farmyard manure, (GN) grain nitrogen, (GP) grain phosphorous, (GK) grain Potassium, ( $\mathrm{C}$ Ca) grain calcium

\section{Declarations}

\section{Ethics approval and consent to participate}

Not applicable

\section{Consent for publication}

Not applicable.

\section{Availability of data and materials}

Not applicable.

\section{Competing interests}

The authors declare that they have no competing interests.

\section{Funding}

Ministry of Education provided fund only for sample collection and laboratory analysis.

\section{Authors' contributions}

ML: collected, analyzed, interpreted the data and made the final write up which was part of his Doctoral thesis in Soil Science at Hawassa University, Ethiopia. BL and LH, as co-authors edited the final manuscript. All authors read and approved the final manuscript.

\section{Acknowledgements}


This research was funded by the grant given to graduate students from the Ethiopian Ministry of Education.

\section{References}

Abewa A, Yitaferu B, Selassie Y.G, Amare T.T (2013) The role of biochar on acid soil reclamation and yield of teff (Eragrostistef [Zucc] Trotter) in northwestern Ethiopia. J Agric Sci 6:1-12.

Abiven S, Hund A, Martinsen V, Cornelissen G (2015) Biochar amendment increases maize root surface areas and branching: a shovelomics study in Zambia. J Plant Soil 395: 45-55.

Agboola K, Moses S.A (2015) Effect of biochar and cowdung on nodulation, growth and yield of soybean (Glycine max I. Merrill) Int J Agric Biol4(4):154-160.

Agegnehu G, Bass AM, Nelson PN, Bird MI (2016) Benefits of biochar, compost and biochar-compost for soil quality, maize yield and greenhouse gas emissions in a tropical agricultural soil. J Sci total Environ 543: 295-306.

Agegnehu G, Lakew B, Nelson P. N (2014) Cropping sequence and nitrogen fertilizer effects on the productivity and quality of malting barley and soil fertility in the Ethiopian highlands. Arch Agron Soil Sci 60: 1261-1275.

Amede T, Belachew T, Geta E (2001) Reversing the degradation of arable land in the Ethiopian Highlands. ManagingAfr.Soils. 23.

Amlinger F,Peyr S, Geszti J, Dreher P, Weinfurtner K, Nortcliff S (2007) Beneficial Effects of Compost Application on Fertility and Productivity of Soils, Federal Ministry for Agricultural and Forestry, Environment and Water Management, Lebensministerium, Vienna, Austria.

Asai H, Samson B.K, Stephan H.M, Songyikhangsuthor K, Homma K, Kiyono Y, Inoue Y, Shiraiwa T, Horie T (2009) Biochar amendment techniques for upland rice production in Northern Laos: 1. Soil physical properties, leaf SPAD and grain yield. Field Crops Res 111: 81-84.

Barrett W, Chu P, Coleman G, Goff D, Griffith L, Hohla J, Jones N, Pohlman K, Poole H, Spiva C, Zwiep J (2017) Agronomy hand book. Midwest laboratories, INC.1311, B. Street, Omaha, NE. 68144, 402, 334, 7770 .

Beukes DJ,Mapumulo TC, Fyfield TP, Jezile GG (2012) Effects of liming and inorganic fertilizer application on soil properties and maize growth and yield in rural agriculture in the Mbizana area, Eastern Cape province, South Africa. South Afr J plant soil.29:3-4.

Bhatta M, Eskridge K.M, Rose D.J, Santra D.K, Baenziger P.S, Regassa T (2017) Seeding rate, genotype, and topdressed nitrogen effects on yield and agronomic characteristics of winter wheat. Crop Sci 57:951-963. 
Bird, M.I (2015) Test procedures for biochar analysis in soils. In: Lehmann J, Joseph S (Eds.), Biochar for Environmental Management. Routledge, London Sci Technol. I Implementation.2:677-714.

Bolan N, Adriano D C, Curtin D (2003) Soil acidification and liming interactions with nutrient and heavy metal transformation and bioavailability. Advances in Agron. 78: 215-272.

Borsari B. (2011) A Preliminary Study of the Effect of Biochar from Maple (Acer spp.) on Root Growth of Selected Agronomic Crops. International Symposium on Growing Media, Composting and Substrate Analysis. 1013:17-22.

CSA (Central Statistics Agency) (2018) Agricultural Sample Survey 2017/2018. Volumel. Report on Area and Production of Major Crops (Private Peasant Holdings, Meher Season). Statistical Bulletin 586. Addis Ababa.

CSA, (Central Statistics Agency).(1995) Agricultural sample survey (1994/95) report: Private peasant holding (Statistical Bulletin) Vol. III Central Statistics Agency, Addis Ababa, Ethiopia.

Dunlop S.J, Arbestain M.C, Bishop P.A, Wargent J.J (2015) Closing the loop: use of biochar produced from tomato crop green waste as a substrate for soilless, hydroponic tomato production. Hort Sci 50: 15721581.

Edmunds C. W (2012) The effects of biochar amendment to soil on bioenergy crop yield and biomass composition. Master's thesis, university of Tennessee, Knoxville.

Efthimiadou A, Bilalis D, Karkanis ,Froud B (2010) Combined organic and inorganic fertilization enhances soil quality and increased yield, photosynthesis and sustainability of sweet maize crop. Aust Crop Sci 4 (9): 722-729.

Enujeke E.C (2013) Effects Of Poultry Manure On Growth And Yield Of Improved Maize In Asaba Area of Delta State, Nigeria. IOSR J Agric Vet Sci 4: 24-30.

Faruque A, Shoriful I.Md, Toufiq I.Md (2017) Biochar amendment improves soil fertility and productivity of mulberry plant. Eurasian J Soil Sci 6 (3): $226-237$.

Gebrekidan H (2003) Grain yield response of sorghum (Sorghum bicolor) to tied ridges and planting methods on EntisolsandVertisolsofAlemaya area, Eastern Ethiopian highlands. J Agric Rural Dev 104(2):113-128.

Gebreselassie Y(2002) Selected chemical and physical characteristics of soils of the Adet research center and its testing sites in North-Western Ethiopia. Eth $J$ Nat Resour 3:199-215.

Gonzaga M.I.S, Mackowiak C.L, Comerford N.B, da Veiga Moline E.F, Shirley J.P, Guimaraes D.V (2017) Pyrolysis methods impact biosolids-derived biochar composition, maize growth and nutrition. Soil Till. Res 165: 59-65. 
Haileselassie G, Haileselassie B, Berhe D, Belay T(2015) Effect of Biochar on Yield and Yield Components of Wheat and Post-harvest Soil Properties in Tigray, Ethiopia. J Fertil Pestic 6(2): 158.

Hossain M. K, Strezov V, Yin Chan K.Y, Nelson P (2010) Agronomic properties of wastewater sludge biochar and bioavailability of metals in production of cherry tomato (Lycopersiconesculentum). Chemosphere 78(9):1167-1171.

Huhm M (1990a) Components on the calculation of mean harvest indices. J Agon Crop Sci 165: 86-93. Jackson M.L (1958) Soil Chemical Analysis. Prentice Hall, Inc., Englewood Cliffs. New Jersey. Jeffrey M, Gilbert C, Thomas F, Donald W, Kenneth C (2019) Stone Designer Biochars Impact on Corn Grain Yields, Biomass Production, and Fertility Properties of a Highly-Weathered Ultisol Environ 6:64.

Lai W-Y, Lai C-M, Ke G-R, Chung R-S, Chen C-T, Cheng C-H, Pai C-W, Chen S-Y, Chen C-C (2013) The effects of woodchip Biochar application on crop yield, carbon sequestration and greenhouse gas emissions from soils planted with rice or leaf beet. J Taiwan Inst Chem. Eng 44 (6): 1039-44.

Laird D. A (2008) The Charcoal Vision: A Win-Win-Win Scenario for Simultaneously Producing Bioenergy, Permanently Sequestering Carbon, while Improving Soil and Water Quality. Agron J100(1).

Lehmann J, Gaunt J, Rondon M (2006) Biochar sequestration in terrestrial ecosystems- a review. Mitigation Adapt Strateg Glob Chang11(2): 403-427.

Lehmann J, Joseph S (2009) Biochar for Environmental Management. Earthscan. London UK. Sci Technol.

Liang F, Li G, Lin Q , Zhao X ( 2014) Crop yield and soil properties in the First 3 years after biochar application to a calcareous Soil $J$ Integr Agric 13:525-532.

Major J, Rondon M, Molina D, Susan J.R, Lehmann J (2010) Maize Yield and Nutrition during 4 Years after Biochar Application to a Colombian Savanna Oxisol. Plant Soil 333: 117-128.

Manuel O, José Antonio A, Vidal B, María C, del C, Antonio G ,Mariano F, Rafael V (2014): Wheat growth and yield responses to biocharaddition under Mediterranean climate conditions. J Bio Fertil Soils 50(8)

Minot N, Warner J, Lemma S, Kassa L, Gashaw A, Rashid S (2015) The Wheat Supply Chain in Ethiopia: Patterns, Trends, and Policy Options. Int Food Policy Res Inst Washington, DC.

Murphy J, Riley J.P (1962) A modified single solution method for the determination of phosphate in natural waters. Anal Chem Acta 27:31-36.

Negash F, Rezene Y (2015) Nitrogen and Phosphorus Fertilizers Rate as Affecting Common Bean Production at Areka, Ethiopia. J Agric Crops 1(3):33-37. 
Okalebo J.R, Gathua K.W, Womer P.L (2002) Laboratory methods of soil and plant analyses: a working manual, 2nd Ed. TSBF - CIAT and SACRED Africa, Nairobi, Kenya.128p.

Pask A.J.D,Pietragalla J, Mullan D, Reynolds M.P (2012) Physiological breeding II: A field guide to wheat phenotyping. CIMMYT, D.F., Mexico. Producing bioenergy, permanently sequestering carbon, while improving soil and water quality. Agron J 100:178-181.

Prapagdee S, Tawinteung N (2017) Effects of biochar on enhanced nutrient use efficiency of green bean, Vigna radiata L. Environ Sci Pollu Res 24:9460-9467.

Ranva R.S, Singh K.P( 2006) Effect of integrated nutrient management with vermin compost on productivity of wheat (Triticumaestivum). Indian J Agron 26 (2):34-37.

SAS (Statistical Analysis System Institute).(2017): SAS/STAT user's guide. Proprietary software version 9.4. SAS Inst Inc Cary NC.

Shahzad M.A, Din W.U, Sahi S.T, Khan M.M, Ehsanullah, Ahmad M (2007) Effect of sowing dates and seed treatment on grain yield and quality of wheat. Pakistan J Agric Sci 44 (4):581-583.

Shoemaker H.E, McLean E.O, Pratt P.F (1961) Buffer methods for determining the lime requirement of soils with appreciable amounts of extractable aluminum. Soil Sci Soc Am 25:274-277.

Solaiman Z.M , Blackwell P, Abbott L.K, Storer P (2010) Direct and residual effect of biochar application on mycorrhizal root colonisation, growth and nutrition of wheat. Soil Res 48: 546-554.

Vanlauwe B, Bationo A, Chianu J, Giller K.E, Merckx R, Mokwunye U, Ohiokpehai O, Pypers P, Tabo R , Shepherd, K.D , Smaling E.M.A, Woomer P.L ,Sanginga N (2010) Integrated soil fertility management: operational definition andconsequences for implementation and dissemination. J Outlook Agric 39:1724.

Waseem M, Ali A, Tahir M, Mehmood K (2013) Mitigative effect of diverse use of nitrogen sources on bulk density, organic matter and grain yield of hybrid maize. Pakistan J Anim Plant Sci 23(3):900-905.

Zahir S, Ishaq A (2006) Effect of integrated use of farm yard manure and urea on yield and nitrogen uptake of wheat. J Agric Biol Sci 1(1).

\section{Tables}

Table 1: ANOVA for the Effect of BC, FYM and lime and their interaction effect on growth parameters of Bread wheat. 


\begin{tabular}{|c|c|c|c|c|c|c|}
\hline Source of variation & $\overline{\mathrm{DF}}$ & \multicolumn{4}{|c|}{$\begin{array}{l}\text { Plant Spike Seedsper spike } \\
\text { heightength }\end{array}$} & Total tillersProductive tillers \\
\hline$\overline{\text { Site }}$ & 1 & ** & ** & ** & ** & ** \\
\hline BC & 2 & ** & ** & $* *$ & ** & ** \\
\hline FYM & 2 & ns & * & * & ns & ns \\
\hline Lime & 2 & $* *$ & ** & ** & $*$ & $*$ \\
\hline Site $x$ BC & 2 & ** & ** & ** & * & * \\
\hline Site $x$ FYM & 2 & $*$ & * & * & ns & ns \\
\hline Site $\mathrm{x}$ Lime & 2 & ns & $*$ & $* *$ & ns & ns \\
\hline BC $x$ FYM & 4 & ns & ns & ns & ns & ns \\
\hline BC x Lime & 4 & ns & ns & ns & ns & ns \\
\hline FYM x Lime & 4 & ns & ns & ns & ns & ns \\
\hline Site $x$ BC $x$ FYM & 4 & * & ns & ns & ns & ns \\
\hline Site $x$ BC $x$ Lime & 4 & ** & ns & ns & ** & ** \\
\hline Site x FYM x Lime & 4 & ns & $\mathrm{ns}$ & ns & ns & ns \\
\hline BC x FYM x Lime & 4 & ns & ns & ns & ns & ns \\
\hline Site $x$ BC x FYM x Lime & 8 & ns & ns & ns & ns & ns \\
\hline
\end{tabular}

Table 2: Effects of BC, FYM and lime on mean values of plant height, spike length, number of seeds per spike, total tillers and productive tillers of Bread wheat.

Table 3: ANOVA for the Effect of BC, FYM, lime and their interaction on total biomass, Grain yield, straw yield and thousand seed weight and harvest index of Bread wheat.

Table 4: Effects of BC, FYM and lime on total biomass, grain yield, straw yield, thousand seed weight and harvest index of Bread wheat.

Table 5: ANOVA for the Effect of BC, FYM and lime and their interaction effect on grain N, $\mathrm{P}, \mathrm{K}$ and Ca concentration of Bread wheat. 


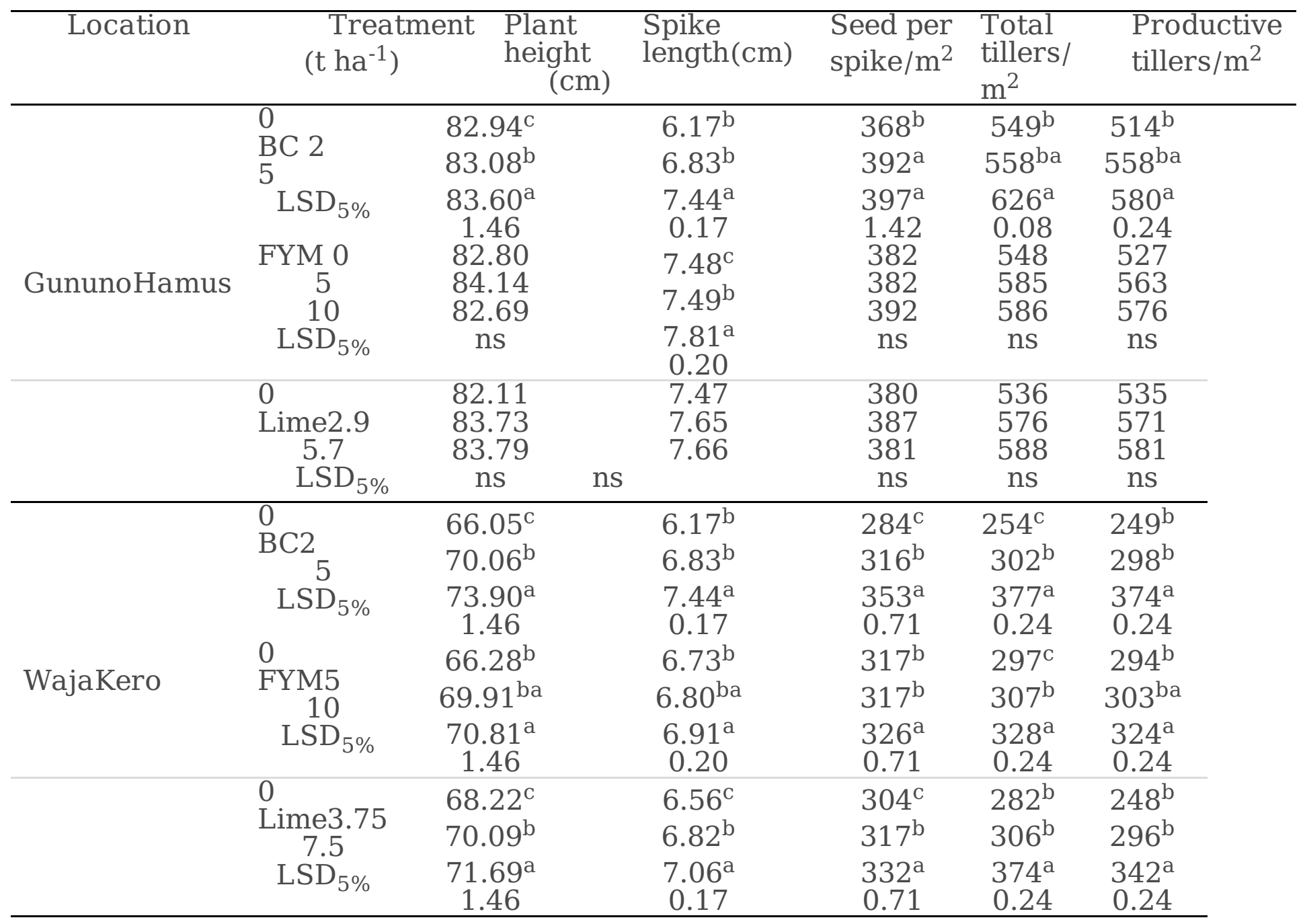

\begin{tabular}{|c|c|c|c|c|c|c|c|}
\hline $\begin{array}{l}\text { Source } \\
\text { variation }\end{array}$ & $\mathrm{fDF}$ & $\begin{array}{l}\text { Total } \\
\text { biomass }\end{array}$ & $\begin{array}{l}\text { Grain } \\
\text { yield }\end{array}$ & $\begin{array}{l}\text { Straw } \\
\text { yield } \\
\end{array}$ & $\begin{array}{l}\text { Thousand } \\
\text { weight }\end{array}$ & seed & $\begin{array}{l}\text { Harvest } \\
\text { index }\end{array}$ \\
\hline Site & 1 & ** & $* *$ & ** & $* *$ & & $* *$ \\
\hline $\mathrm{BC}$ & 2 & ** & ** & ** & $* *$ & & ** \\
\hline FYM & 2 & ** & $* *$ & ** & $*$ & & * \\
\hline Lime & 2 & ** & $* *$ & $* *$ & $* *$ & & ns \\
\hline Site x BC & 2 & ** & $* *$ & $* *$ & * & & $*$ \\
\hline Site x FYM & 2 & ns & ns & ns & ns & & ns \\
\hline Site $x$ Lime & 2 & ** & $* *$ & $* *$ & ns & & ns \\
\hline $\mathrm{BC} \times \mathrm{FYM}$ & 4 & ns & ns & * & $* *$ & & $*$ \\
\hline BC x Lime & 4 & ns & ns & ns & ns & & ns \\
\hline FYM x Lime & 4 & ns & ns & ns & ns & & ns \\
\hline Site $\times$ BC $\times$ FYM & 4 & ns & ns & ns & ns & & ns \\
\hline Site $x$ BC $\times$ Lime & 4 & ** & $* *$ & ** & ns & & ns \\
\hline Site x FYM x Lime & 4 & ns & ns & ns & ns & & ns \\
\hline BC $x$ FYM x Lime & 4 & ns & ns & ns & ns & & ns \\
\hline $\begin{array}{l}\text { Site x BC x FYM x } \\
\text { Lime }\end{array}$ & 88 & ns & ns & ns & ns & & ns \\
\hline
\end{tabular}

Table 6: Effect of BC, FYM and lime on grainN, P, K and Ca concentration of bread wheat. 


\begin{tabular}{|c|c|c|c|c|c|c|c|}
\hline Location & $\begin{array}{l}\text { Treatment } \\
\text { tha }^{-1}\end{array}$ & $\begin{array}{l}\text { Total } \\
\text { biomass } \\
\left(\mathrm{Kg} \mathrm{ha}^{-1}\right)\end{array}$ & $\begin{array}{l}\text { Grain } \\
\text { yield } \\
\text { (Kg ha- }\end{array}$ & & & $\begin{array}{l}\text { Thousand } \\
\text { seed } \\
\text { weight }(g)\end{array}$ & $\begin{array}{l}\text { Harvest } \\
\text { Index } \\
(\%)\end{array}$ \\
\hline \multirow{4}{*}{ GununoHamus } & \begin{tabular}{l}
$\quad 0$ \\
\multicolumn{2}{c}{${ }^{2}$} \\
BC5 $^{2}$ \\
LSD $_{5 \%}$
\end{tabular} & $\begin{array}{l}7926^{\mathrm{b}} \\
8144^{\mathrm{b}} \\
8434^{\mathrm{a}} \\
0.27^{\mathrm{a}}\end{array}$ & $\begin{array}{l}2595^{\mathrm{c}} \\
3312^{\mathrm{b}} \\
3593^{\mathrm{a}} \\
0.15\end{array}$ & $\begin{array}{l}4039^{\mathrm{c}} \\
5114^{\mathrm{b}} \\
5880^{\mathrm{a}} \\
0.27\end{array}$ & \multicolumn{2}{|c|}{$\begin{array}{l}45.56^{\mathrm{c}} \\
50.00^{\mathrm{b}} \\
52.15^{\mathrm{a}} \\
0.10^{\mathrm{a}}\end{array}$} & $\begin{array}{l}37.91 \\
39.11 \\
39.44 \\
\text { ns }\end{array}$ \\
\hline & $\begin{array}{l}0 \\
\text { FYM5 } \\
10 \\
\quad \text { LSD }_{5 \%}\end{array}$ & $\begin{array}{l}6634^{\mathrm{c}} \\
8397^{\mathrm{b}} \\
9473^{\mathrm{a}} \\
0.23\end{array}$ & $\begin{array}{l}3051^{\mathrm{b}} \\
3104^{\mathrm{b}} \\
3346^{\mathrm{a}} \\
0.15\end{array}$ & $\begin{array}{l}4824^{\mathrm{b}} \\
5094^{\mathrm{ba}} \\
5198^{\mathrm{a}} \\
0.27\end{array}$ & \multicolumn{2}{|c|}{$\begin{array}{l}45.56^{\mathrm{b}} \\
50.00^{\mathrm{b}} \\
55.12^{\mathrm{a}} \\
0.10^{4}\end{array}$} & $\begin{array}{l}37.59^{\mathrm{b}} \\
38.84^{\mathrm{ba}} \\
39.93^{\mathrm{a}} \\
0.16\end{array}$ \\
\hline & $\begin{array}{c}0 \\
\text { Lime } 2.9 \\
5.7 \\
\text { LSD }_{5 \%}\end{array}$ & $\begin{array}{l}7466^{\mathrm{c}} \\
8286^{\mathrm{b}} \\
8752^{\mathrm{a}} \\
0.27 \\
\end{array}$ & $\begin{array}{l}2929^{c} \\
3205^{b} \\
3366^{a} \\
0.15 \\
\end{array}$ & $\begin{array}{l}4399^{\mathrm{c}} \\
4563^{\mathrm{b}} \\
4788^{\mathrm{a}} \\
0.27 \\
\end{array}$ & \multicolumn{2}{|c|}{$\begin{array}{l}46.67^{\mathrm{c}} \\
50.74^{\mathrm{b}} \\
53.33^{\mathrm{a}} \\
0.10\end{array}$} & $\begin{array}{l}38.03 \\
38.11 \\
38.74 \\
\text { ns }\end{array}$ \\
\hline & $\begin{aligned} & \text { BC2 } 0 \\
& 5 \\
& \text { LSD }_{5 \%}\end{aligned}$ & $\begin{array}{l}4442^{\mathrm{c}} \\
6145^{\mathrm{b}} \\
6633^{\mathrm{a}} \\
0.74\end{array}$ & $\begin{array}{l}1573^{\mathrm{c}} \\
2395^{\mathrm{b}} \\
2708^{\mathrm{a}} \\
0.27\end{array}$ & $\begin{array}{l}2735^{\mathrm{c}} \\
3813^{\mathrm{b}} \\
5343^{\mathrm{a}} \\
0.63\end{array}$ & & $\begin{array}{l}44.44^{\mathrm{c}} \\
51.11^{\mathrm{b}} \\
57.78^{\mathrm{a}} \\
0.02\end{array}$ & $\begin{array}{l}34.59^{\mathrm{c}} \\
35.33^{\mathrm{b}} \\
38.67^{\mathrm{a}} \\
0.25\end{array}$ \\
\hline \multirow[t]{2}{*}{ WajaKero } & $\begin{array}{c}0 \\
\text { FYM } 5 \\
10 \\
\text { LSD }_{5 \%}\end{array}$ & $\begin{array}{l}5865^{\mathrm{c}} \\
6068^{\mathrm{b}} \\
7978^{\mathrm{a}} \\
0.74 \\
\end{array}$ & $\begin{array}{l}2106 \\
2233 \\
2337 \\
\text { ns }\end{array}$ & $\begin{array}{l}3684^{\mathrm{b}} \\
3851^{\mathrm{ba}} \\
4356^{\mathrm{a}} \\
0.63 \\
\end{array}$ & & $\begin{array}{l}50.00 \\
51.48 \\
52.85 \\
\text { ns }\end{array}$ & $\begin{array}{l}35.44 \\
36.52 \\
36.60 \\
\text { ns }\end{array}$ \\
\hline & $\begin{array}{c}0 \\
\text { Lime } 3.75 \\
7.5 \\
\text { LSD }_{5 \%}\end{array}$ & $\begin{array}{l}5368^{b} \\
6045^{b} \\
7153^{a} \\
0.74 \\
\end{array}$ & $\begin{array}{l}1955^{b} \\
2258^{b} \\
2463^{a} \\
0.25 \\
\end{array}$ & $\begin{array}{l}3369^{\mathrm{b}} \\
3781^{\mathrm{b}} \\
4741^{\mathrm{a}} \\
0.63 \\
\end{array}$ & & $\begin{array}{l}48.07^{\mathrm{b}} \\
50.74^{\mathrm{b}} \\
54.07^{\mathrm{a}} \\
2.71 \\
\end{array}$ & $\begin{array}{l}35.52 \\
35.26 \\
37.11 \\
\text { ns }\end{array}$ \\
\hline
\end{tabular}

\begin{tabular}{lllllc}
\hline Source of variation & DF & GN & GP & GK & GCa \\
\hline Site & 1 & $* * *$ & $* * *$ & $* * *$ & $* * *$ \\
BC & 2 & $* * *$ & $* * *$ & $* * *$ & $*$ \\
\hline FYM & 2 & $* * *$ & $*$ & $* * *$ & $* *$ \\
\hline Lime & 2 & $* * *$ & $* *$ & $* *$ & $* * *$ \\
\hline Site x BC & 2 & ns & $* * *$ & ns & ns \\
\hline Site x FYM & 2 & ns & ns & ns & ns \\
\hline Site x Lime & 2 & ns & ns & ns & ns \\
\hline BC x FYM & 4 & ns & ns & $*$ & ns \\
\hline BC x Lime & 4 & $*$ & $* *$ & $* *$ & ns \\
\hline FYM x Lime & 4 & ns & ns & $* *$ & ns \\
\hline Site x BC x FYM & 4 & ns & ns & ns & ns \\
\hline Site x BC x Lime & 4 & ns & ns & ns & $* *$ \\
\hline Site x FYM x Lime & 4 & ns & ns & ns & ns \\
BC x FYM x Lime & 4 & ns & ns & $* *$ & ns \\
\hline Site x BC x FYM x Lime & 8 & ns & ns & $* *$ & ns \\
\hline
\end{tabular}




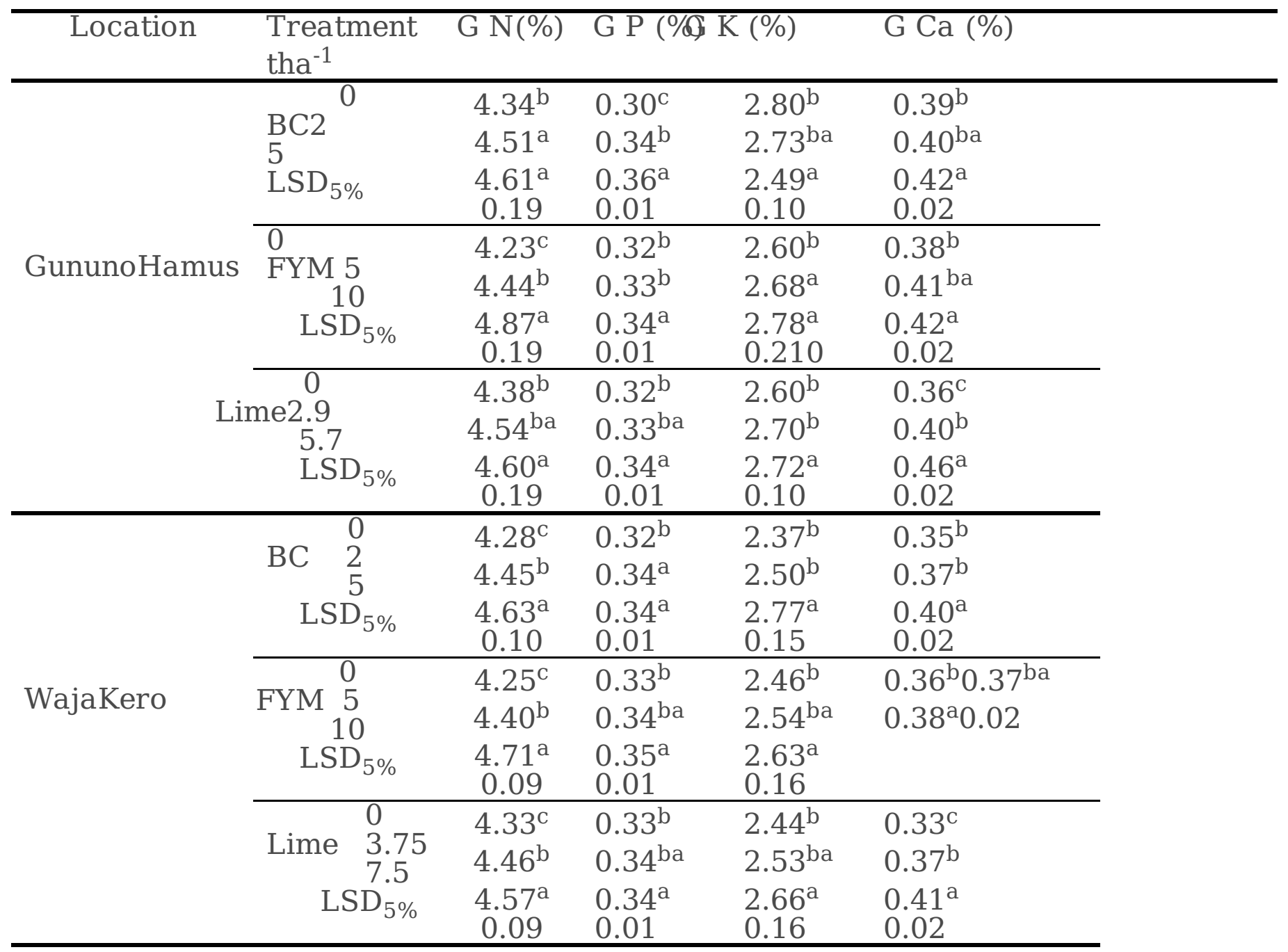




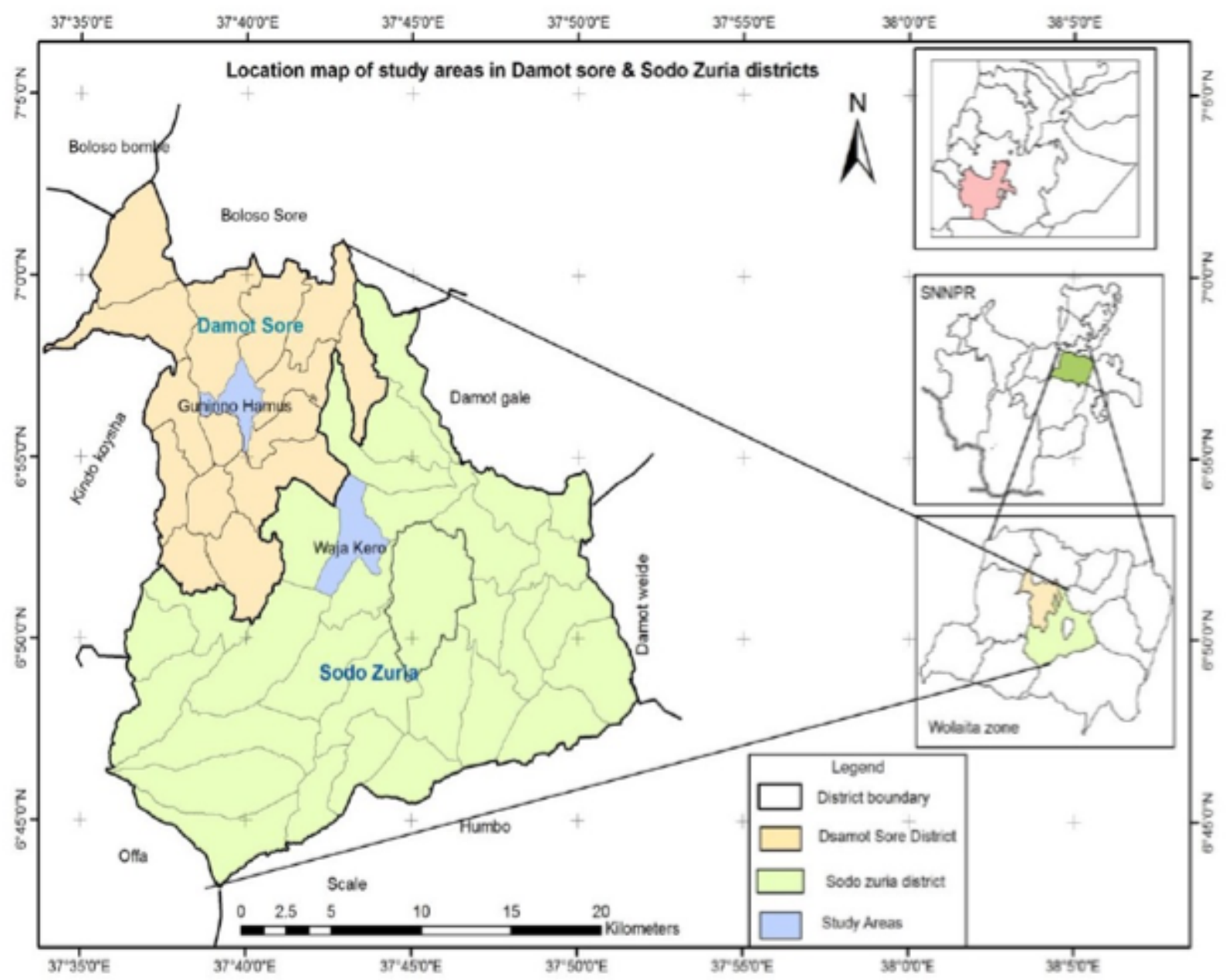

Figure 1

Location map of the study areas in Wolaita Zone (Damote sore and SodoZuria Districts). 


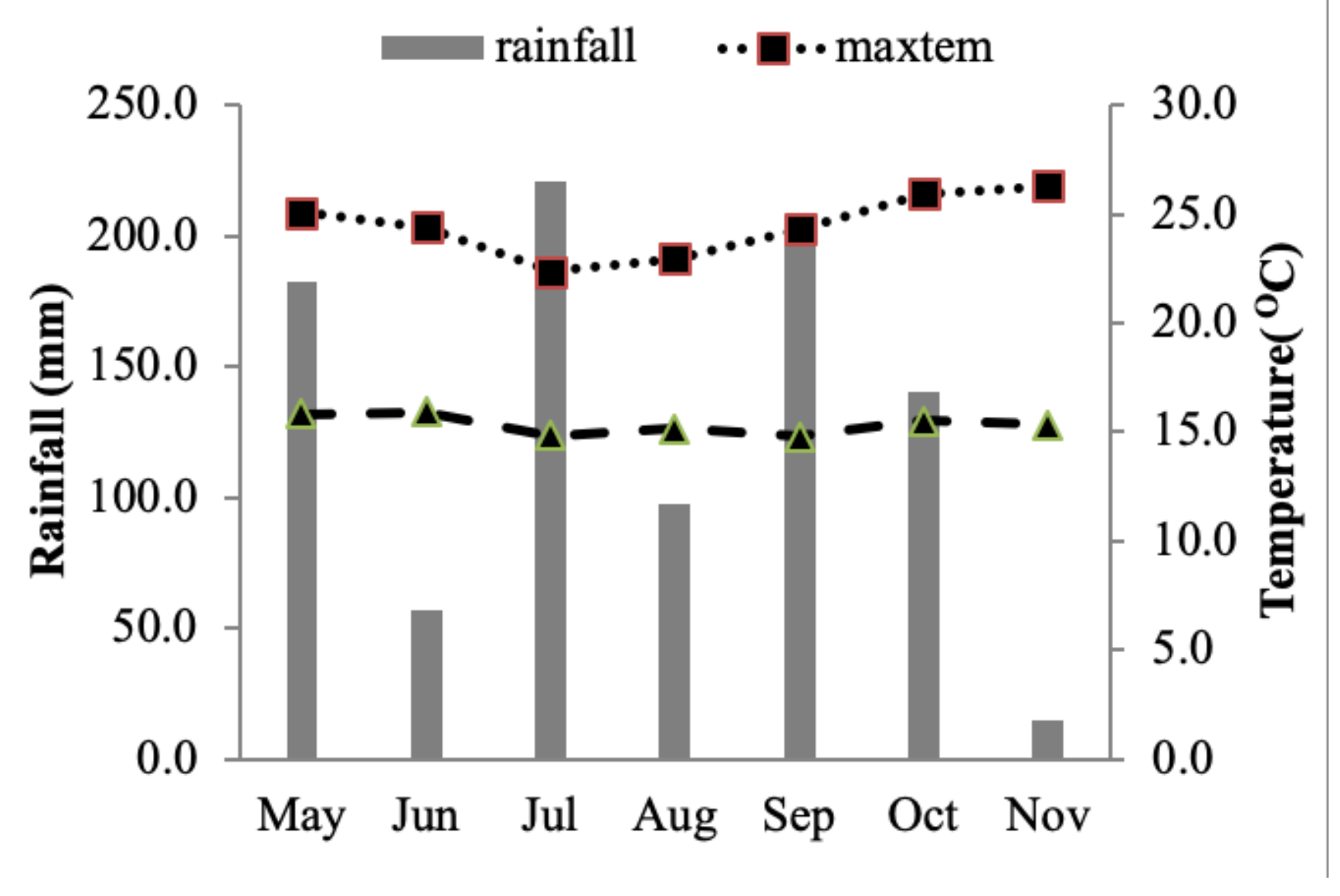

Figure 4

Mean monthly total rainfall $(\mathrm{mm})$, maximum and minimum temperatures $\left({ }^{\circ} \mathrm{C}\right)$ of the study areas from 2016-2017 (Source: National Meteorological Agency, Hawassa branch).

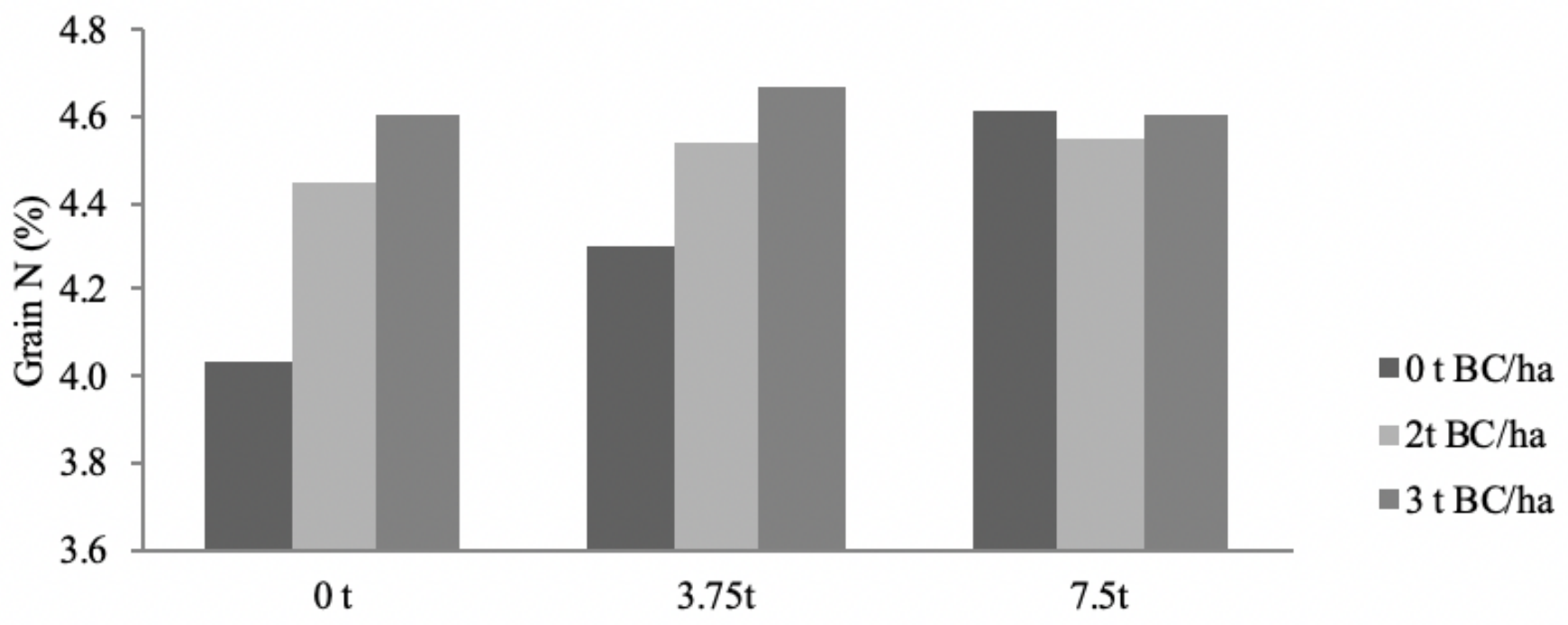

Lime rate ha ${ }^{-1}$ 
Figure 6

The Effect of BC and Lime interaction on grain N content (\%) of wheat.

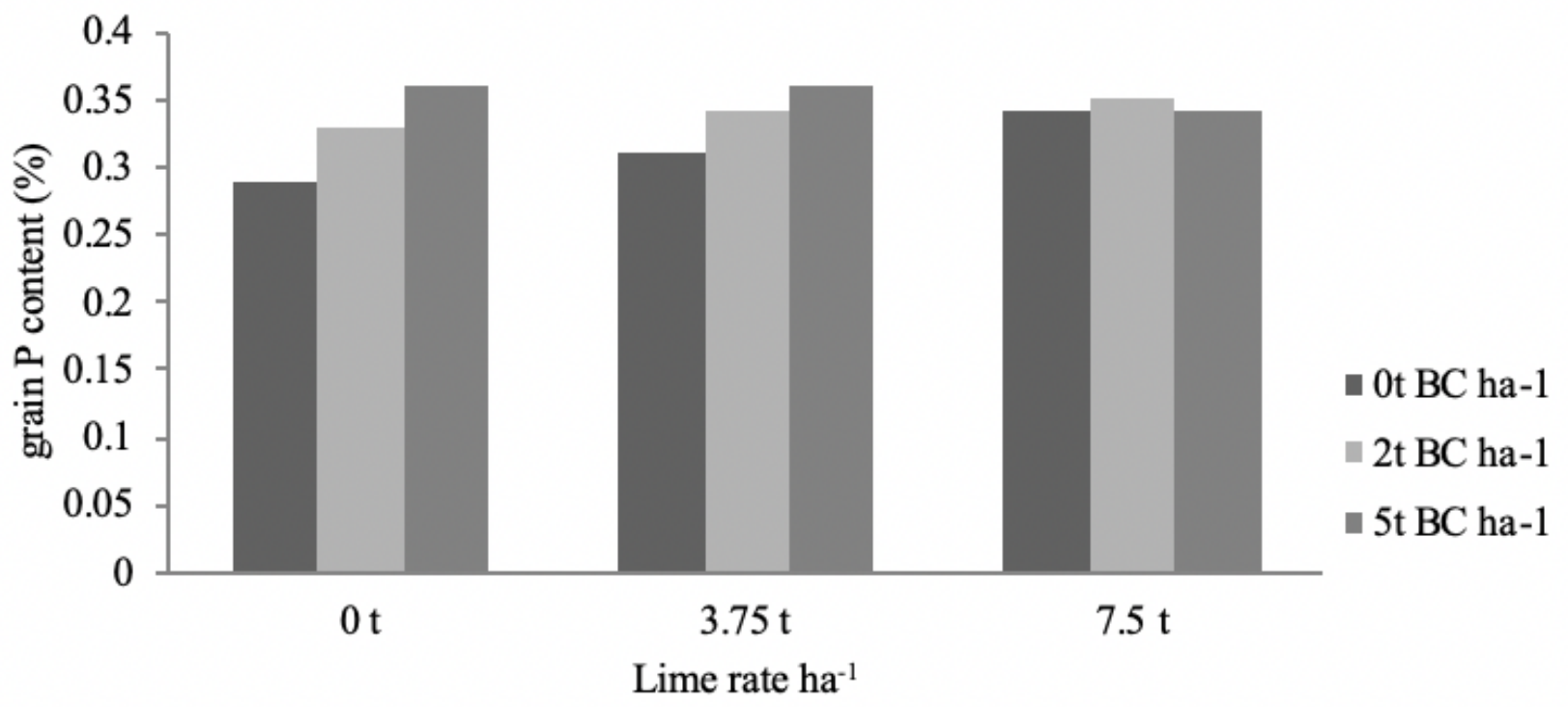

Figure 8

The effect of $B C$ and lime interaction on grain $\mathrm{P}$ content of wheat.

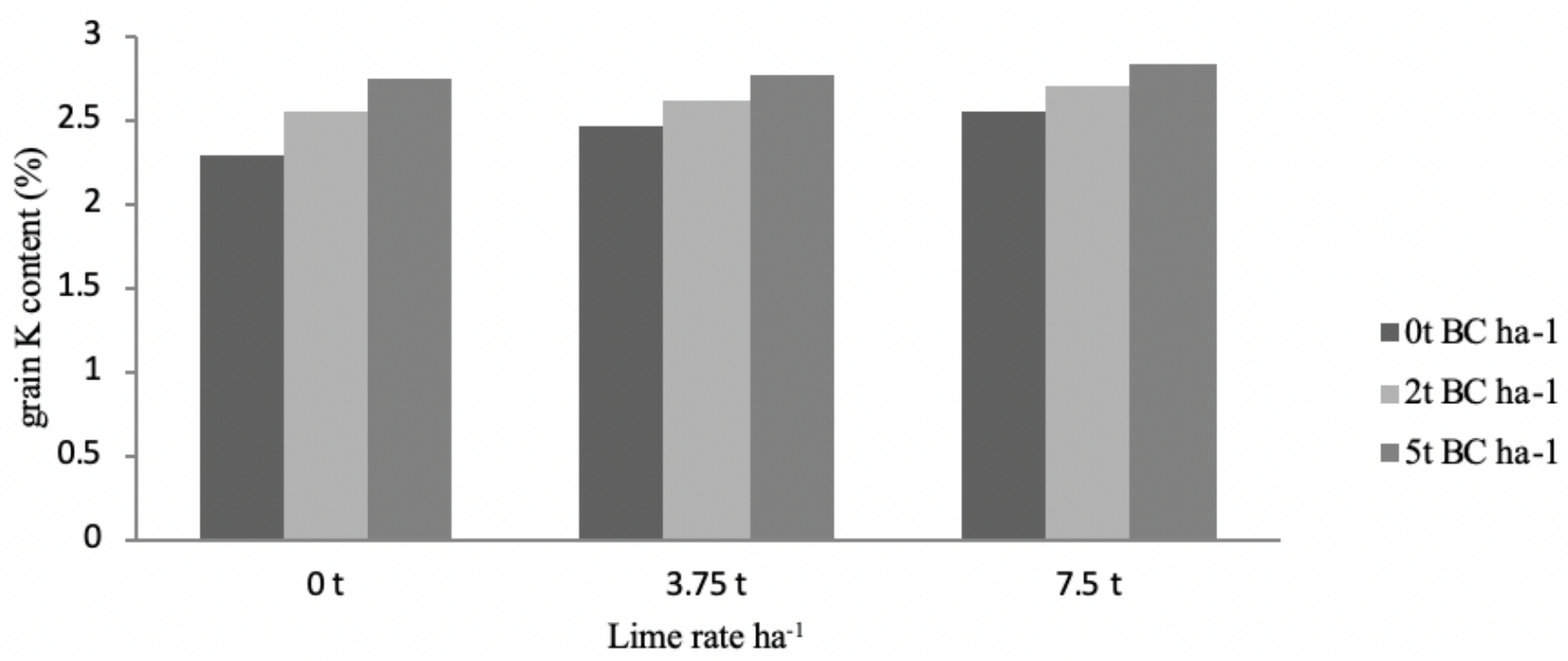

Figure 9

The effect of $\mathrm{BC}$ and lime interaction on grain $\mathrm{K}$ content of wheat. 